$\rightarrow$ DOI : 10.15740/HAS/AJBS/10.1/89-100

e ISSN-0976-8343 | $\quad$ Visit us : www.researchjournal.co.in
ASIAN JOURNAL OF BIO SCIENCE

Volume 10 | Issue 1 | April, 2015 | 89-100

\title{
A REVIEW \\ A study of alcohol and its side effect on human physiology
}

\author{
DEBASISH KUMAR DEY AND MEENU SINGH
}

Department of Biosciences, Barkatullah University, BHOPAL (M.P.) INDIA

Email : deepdey1993@gmail.com

Article Info : Received : 04.12.2014; Accepted : 22.03.2015

From the very beginning of ancient time we are using alcohol as a part of our culture just to enhance the fun in different ceremonies, but drinking too much of alcohol or indulging it into one's habit can cause serious problems to one's health such as various cancer, alcoholic hepatitis, cirrhosis, pancreatitis and so on. Not only this much even some time may it lead to a serious accident. But of course this is very true that "Alcohol affects different people differently" as per the tolerance level of an individual. As per Plato "The excessive increase of anything causes a reaction in the opposite direction" the same applies here too in case of alcohol. In fact a moderate drinking has also been proved that it has some positive effects on the body. It only effects negatively to the body when the concentration of alcohol in the blood will be relatively higher say $5-10 \mathrm{~m} \mathrm{~mol} \mathrm{~L}^{-1}$ and also at low concentration of alcohol there will be a feeling of euphoria. According to the book "Beyond hangovers" A research demonstrates "low risk" drinking level for men are no more than four drinks per day and fourteen in a week, at the same time three drinks in a day and seven drinks in a week for women. Even after drinking moderately one may have problems, if one drinks too quickly; this case is considered only for those who are over age 65. And for older adults, they should not take more than three drinks in a day and seven drinks in a week. When someone drinks beverage alcohol around 2 per cent to 8 per cent is lost through urine and sweat. The other 92 per cent to 98 per cent is metabolized by our body. At the same time alcohol exerted its effects on CNS by nonselectivity disrupting the lipid bilayers of neurons. Actually alcohol passes directly from the digestive tract into the blood vessels. Within minutes, the blood transports the alcohol to all parts of the body, including the brain. And it affects the brain's neurons in several ways. It also alters their membranes as well as their ion channels, enzymes and receptors. Alcohol also binds directly to the receptors for acetylcholine, serotonin, GABA and also with the NMDA receptors for glutamate.GABA's effect is to reduce neural activity by allowing chloride ions to enter the post-synaptic neuron. These ions have a negative electrical charge, which helps to make the neuron less excitable. This physiological effect is amplified when alcohol binds to the GABA receptor, because it enables the ion channel to stay open longer and thus let more $\mathrm{Cl}^{-}$ions into the cell. The neuron's activity would thus, be further diminished, thus, explaining the sedative effect of alcohol. This effect is accentuated because alcohol also reduces glutamate's excitatory effect on NMDA receptors.

Key words : Drug, Alcohol, GABA, GABA receptors, $\mathrm{CNS}, \mathrm{Cl}^{-}$ions

How to cite this paper : Dey, Debasish Kumar and Singh, Meenu (2015). A study of alcohol and its side effect on human physiology. Asian J. Bio. Sci., 10 (1) : 89-100. 